\title{
CIVIL LIABILITY FOR VIOLATION OF NASD RULES: SEC v. FIRST SECURITIES CO.
}

In a recent case, $S E C$ v. First Securities Co. ${ }^{1}$ the Seventh Circuit held a brokerage firm liable for damages incurred by clients as a result of its failure to inspect and review the business correspondence of an employee. This failure was a violation of section 27 of the National Association of Security Dealers (NASD) Rules of Fair Practice. ${ }^{2}$ "Such violations provide a basis for private damage actions where the rule violated serves to protect the public,"3 said the court. The decision is the first by a federal court to hold an NASD member liable in a civil action for violation of an NASD rule.

This Comment will analyze the Seventh Circuit's basis for finding civil liability in First Securities and other related cases. This theory will be compared to that suggested by the Second Circuit, and will be evaluated with regard particularly to its impact upon the NASD's increasingly litigated ${ }^{4}$ suitability rule. ${ }^{5}$ Broadly read, the Seventh Circuit's approach ${ }^{6}$ would appear to impose federal civil liability for violation of any NASD Rules of Fair Practice whereas the Second Circuit $^{7}$ would differentiate between ethical standards of professional service and rules designed to prevent fraud. The latter would appear the more valuable approach, for it enables the federal courts either to decline to extend civil liability for violation of professional ethical standards, or to create liability with the full awareness that they are adopting mere standards of professional conduct which require considerable development.

\section{The First Securities Decision}

Leston B. Nay, President of First Securities and owner of $92 \%$ of its stock, convinced several of the firm's regular clients to invest in an "escrow." The funds invested were to serve as the principal for a

1 [1971-1972 Transfer Binder] CCH FED. SEC. L. REp. ff 93,430 (7th Cir., Apr. 12, 1972).

2 CCH NASD MANUAL I 2177. Rule 27 provides in part:

(a) Each member shall establish, maintain and enforce written procedures which will enable it to supervise properly the activities of each registered representative and associated person to assure compliance with applicable securities laws, rules, regulations and statements of policy promulgated thereunder and with the rules of this Association.

3 [1971-1972 Transfer Binder] CCH Fed. SEC. L. REP. If 93,430, at 92,139.

${ }^{4}$ For a discussion of one pending case brought under the suitability rule, see Belliveau, Discretion or Indiscretion, INST. INv., Aug. 1972, at 65.

5 CCH NASD MANUAL art. III, § 2, II 2152.

6 See, e.g., Avern Trust v. Clarke, 415 F.2d 1238 (7th Cir. 1969). Cf. Buttrey v. Merrill Lynch, Pierce, Fenner \& Smith, Inc., 410 F.2d 135 (7th Cir.), cert. denied, 396 U.S. 838 (1969).

7 See, e.g., Colonial Realty Corp. v. Bache \& Co., 358 F.2d 178 (2d Cir.), cert. denied, 385 U.S. 817 (1966). 
small loan company which would lend at interest rates up to $21 / 2 \%$ per month. Annual returns on this special opportunity were promised to be in the vicinity of 9 to $12 \%$. Clients thus sold other securities through the brokerage firm in order to obtain the necessary cash to invest in the escrow.

The dealings were not conducted, however, in the manner typical of the company. Nay acknowledged the claimants' investments by means of a handwritten document. He used his personal checks to make interest payments and deducted these payments from his personal income for tax purposes. Over the course of fifteen years the payments became less regular, until it was revealed that the firm was bankrupt and the escrow nonexistent. The SEC instituted a receivership action and the clients sought to recover against the assets of the company. It was established that the firm had no actual knowledge of its president's fraudulent activity and had granted no actual authority to him to conduct the escrow dealings. Significantly, however, the company did enforce a rule that no mail addressed to the president was to be opened by any other employee. The district court dismissed the claims.

In reversing the lower court's decision, the Court of Appeals for the Seventh Circuit held the firm liable under four different theories: the apparent authority of the president to deal in the escrow, under common law agency; $;^{8}$ the "controlling person status" of the firm with respect to its employee, under the Securities Exchange Act of $1934 ;^{\circ}$ the "aiding and abetting" position assumed by the firm in its failure to check the president's correspondence under rule $10 \mathrm{~b}-5$ of the SEC; ${ }^{10}$ and the violation of the NASD Rules of Fair Practice, ${ }^{11}$ mentioned above. This Comment concentrates on the last of the claims recognized, and specifically the standard the court employed in finding a private cause of action for the violation of an NASD rule.

The first case to deal specifically with the issue of whether a

8 Restatentent (SeCOND) of Agency $\S \S 261,262$ (1958).

15 U.S.C. \& $78 t$ (a) (1970).

1017 C.F.R. \$ 240.10b-5 (1972). The court held that aiding and abetting may be founded on less than actual knowledge and participation in the activity proscribed by rule 10b-5. [1971-1972 Transfer Binder] CCH FED. SEC. L. REP. $\mathbb{1}$ 93,430, at 92,139. Although the opinion might be read to reject a scienter requirement, the court did stress the firm's recklessness in enforcing the president's order not to open his mail. Id. Such abandon may satisfy the scienter requirement traditionally associated with aiding and abetting. Reckless disregard for the truth of representations made by a co-participant in the course of common activity may be legally equivalent to a knowing assistance in fraud. See Ruder, Multiple Defendants in Securities Lare Fraud Cases: Aiding and Abetting, Conspiracy, In Pari Delicto, Indemnification, and Contribution, 120 U. PA. L. Rev. 597, 630-38 (1972). Cf. Trussel v. United Underwriters, Itd., 228 F. Supp. 757 (D. Colo. 1964). For a case suggesting that the Seventh Circuit might demand something less than scienter, see Buttrey v. Merrill Lynch, Pierce, Fenner \& Smith, Inc., 410 F.2d 135, 144 (7th Cir.), cert. denied, 396 U.S. 838 (1969) (holding that a claim for relief based on aiding and abetting securities fraud is stated if it is alleged that the defendant knew or should have known of fraudulent activity and enabled that activity to continue).

11 CCH NASD MANUAL art. III, § 27, II 2177. 
brokerage firm could be held liable in a private cause of action for a violation of an SEC or NASD rule was Colonial Realty Corp. v. Bache \& $\mathrm{Co}^{12}$ There the plaintiff claimed that defendant, Bache, a New York Stock Exchange (NYSE) member, breached an oral agreement by requiring margin in excess of the minimum requirements of the NYSE and that as a result of Bache's demands it suffered losses, "running into millions of dollars, and some $\$ 100,000$ in commissions which Bache had collected."13 Under the NYSE constitution, a member who is found guilty of "conduct or proceeding inconsistent with just and equitable principles of trade may ... be suspended or expelled."14 The plaintiff believed that the breach of the oral agreement violated such "just and equitable principles of trade" which were referred to not only in the NYSE constitution but also in other statutory regulations. ${ }^{15}$

The lower court dismissed the federal claim indicating that violation of association exchange rules does not give rise to suits in federal courts. The Second Circuit affirmed the decision, but only after carefully analyzing the rule and creating a test which requires a judicial investigation of the particular rule involved with regard to its function in securities regulation. Pursuant to this, "a court must look to the nature of the particular rule and its place in the regulatory scheme, with the party urging the implication of a federal liability carrying a considerably heavier burden of persuasion than when the violation is of the statute or an SEC regulation."16

In essence, the Second Circuit expressed its belief that the principle of Baird v. Franklin ${ }^{17}$ - that failure by a stock exchange to enforce rules adopted pursuant to section $6(\mathrm{~b})$ of the Securities Exchange Act of 1934 could give rise to a federal claim against the exchange by an investor-should not necessarily be extended to allow the injured investor to sue a member of the self-regulatory body for the latter's failure to conform to such rules. While mentioning several tests to be used in finding the existence of a private cause of action under NASD rules, the court declared two general criteria: (1) "explicit statutory condemnation of certain conduct and a general grant of jurisdiction to enforce liabilities created by the statute"; ${ }^{18}$ and (2) "such considerations as the protection intended by the legislature and the ineffectiveness of existing remedies, administrative and judicial remedies, to fully

12358 F.2d 178 (2d Cir.), cert. denied, 385 U.S. 817 (1966).

13 Id. at 179.

14 NYSE CoNsT. art. XIV, § 6.

15 See, e.g., $\S \S 6(\mathrm{~b})$ and $15 \mathrm{~A}(\mathrm{~b})(8)$ of the Securities Exchange Act of 1934, 15 U.S.C. $\$ \S 78 \mathrm{f}(\mathrm{b}), 780-3(\mathrm{~b})(8)$ (1970); CCH NASD MANUAL art. I, \& 2(a), II 1102; id. art. III, \& 1, II 2151.

16358 F.2d 178, 182 (2d Cir.), cert. denied, 385 U.S. 817 (1966).

17141 F.2d 238 (2d Cir. 1944).

18358 F.2d at 181. 
achieve that end."19 The court went on to state that a rule offered as a basis for a private action would be most acceptable were it to present a specific rather than a vague, general admonition. That is, it should be "a substitute for regulation by the SEC itself" to impose "an explicit [legal] duty unknown to the common law."20

While indicating that it would not take the position that there could never be a basis for implying a private right of action based on an exchange or association rule, the court proceeded to express its belief that there would not be, a fortiori, civil liability for violation of rules prohibiting conduct which is "inconsistent with just and equitable principles of trade."21 In the court's opinion, the scope of these rules includes "unethical behavior which Congress could well not have intended to give rise to a legal claim" $;{ }^{22}$ from this, the court found no reason to believe that merely by requiring adoption of rules assuring fair and equitable conduct, "Congress meant to impose a new legal standard on members different from that long recognized by state law."23 Accordingly, the court denied the plaintiff any cause of action, holding that the NASD's general business conduct rule did not supply an adequate basis for the implication of a private remedy.

An analysis of the post-Colonial Realty cases reveals that courts have not been uniform in the application of the tests which that case promulgates. Indeed First Securities represents the last in a series of cases, decided by the Seventh Circuit, which has invoked the use of a quite different set of standards.

Buttrey v. Merrill Lynch, Pierce, Fenner \& Smith, Inc. ${ }^{24}$ arose out of a suit by the trustee in bankruptcy for a bankrupt brokerage firm. This case involved a claim by the trustee in bankruptcy against Merrill Lynch for violation of rule 405 of the NYSE which requires "due diligence to learn the essential facts relative to every customer, every order, every cash or margin account accepted or carried by a member organization ...."25 It was alleged that the defendant had allowed the president of the bankrupt brokerage firm to maintain cash and margin accounts for the purpose of speculation without inquiring into his financial responsibility or the source of his funds. The plaintiff also claimed Merrill Lynch had allowed the speculation to continue after it learned that the funds were those of customers and not the bankrupt's own. Losses sustained in trading with defendant were said to be the direct cause of the bankruptcy.

While the Buttrey decision did not involve an NASD rule, but

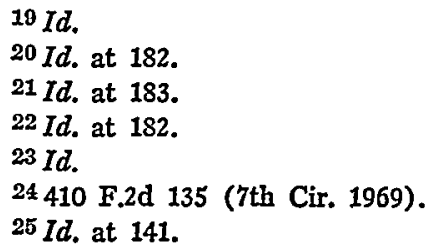


rather the NYSE's rule 405, the Seventh Circuit proceeded to discuss the Colonial Realty opinion, evidently believing that the question of the existence of a private cause of action under the NYSE's selfregulatory rule raised issues similar to those under the NASD rule. Without explicitly rejecting the Colonial Realty opinion, the Buttrey court ignored such factors as whether the self-regulatory rule imposed a duty unknown at common law or could be viewed as a substitute for SEC regulation. As to whether an NYSE rule might give rise to a private cause of action, the court concluded:

The touchstone for determining whether or not the violation of a particular rule is actionable should properly depend upon its design "for the direct protection of investors." . . . Here one of the functions of Rule 405 is to protect the public, so that permitting a private action for its violation is entirely consistent with the purposes of the statute. ${ }^{26}$

Having determined that permitting a private cause of action under rule 405 would not be inconsistent with "the purposes of the statute,"27 the court went on to suggest what the elements of the proposed cause of action would be. The court specifically did "not decide that an alleged violation of rule 405 is per se actionable." 28

Although mere errors of judgment by defendant might not support a federal cause of action, the facts alleged here are tantamount to fraud on the bankrupt's customers, thus giving rise to a private civil damage action. ${ }^{29}$

In a case subsequent to Buttrey, Avern Trust v. Clarke, ${ }^{30}$ the Seventh Circuit spoke again largely in terms of rules designed to protect the public. Also again, a finding of fraud was directly relevant to the court's disposition of the case. Indeed, the court stated that, "Section 2 of Article III of the [NASD's] Rules of Fair Practice is intended 'for the direct protection of investors," " and citing its decision in Buttrey, concluded that the dismissal of the cause of action based upon the suitability rule had been improper. It then proceeded, however, to declare that the dismissal had not prejudiced the plaintiff's case, in that the same suitability violation theory was incorporated under the claim for violation of section 15 of the 1934 Act. ${ }^{31}$ Thus, the court found that while a private cause of action does in fact exist for violation of the NASD's suitability rule, the suitability violation in that case was of such a nature as to be covered by one of the antifraud provisions of the 1934 Act.

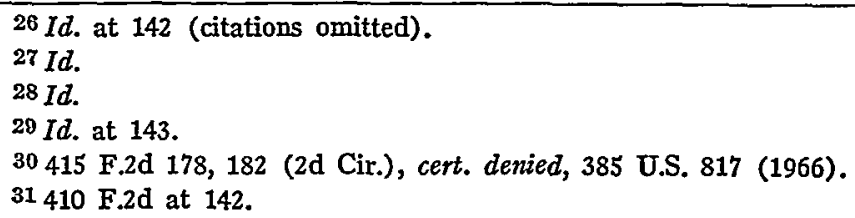


The language of Buttrey, Avern, and First Securities indicates that a claim will be recognized for a violation of any NASD rule intended for the protection of the public. The additional requirement of fraudulent conduct has not yet been firmly established and has been questioned by courts as well as commentators. ${ }^{32}$ Such language is broad enough to encompass all the NASD Rules of Fair Practice. This is just the indiscriminate fashioning of rules violations into torts that Colonial Realty rejected. ${ }^{33}$

Integral to what the Second Circuit believed must form the basis of a reasonable approach to civil liability for violations of NASD rules is concern with the effect of that civil liability on the statutory scheme of cooperative regulation and the appropriateness of judicially enforcing ethical standards. ${ }^{34}$ Friendly's substitution test-that courts should allow private recovery for violations of rules which substitute for or play an integral part in SEC regulation-reflects these concerns and leaves the courts allowing recovery in cases involving so-called legal prohibitions and denying recovery in cases involving the ethical questions which do not lend themselves readily to judicial enforcement.

Under the Maloney Act ${ }^{35}$ of 1938 the promulgation and enforcement of rules designed to promote just and equitable principles of trade in over-the-counter markets were committed to registered security dealers associations. ${ }^{36}$ The powers of the SEC in regulation of overthe-counter markets have traditionally related primarily to fraudulent activity and disclosure requirements. While the scope of SEC activity has broadened since its inception in 1934, it remains true today that one of the fundamental advantages of the cooperative regulatory scheme is that the self-regulatory bodies can enforce ethical standards above and beyond those that can be enforced as a matter of law. ${ }^{37}$

\footnotetext{
32 Such was the interpretation placed on Buttrey by the federal district court in Aetna Cas. \& Sur. Co. v. Paine, Webber, Jackson \& Curtis, [1969-1970 Transfer Binder] CCH FED. SEC. L. REP. If 92,748 (N.D. III. 1970). For an interpretation that the existence of fraud was only sufficient and not necessary for the imposition of civil liability, see Wolfson \& Russo, The Stock Exchange Member: Liability for Violation of Stock Exchange Rules, 58 Carre. L. Rev. 1120, 1131 (1970).

33358 F.2d 178, 182 (2d Cir.), cert. denied, 385 U.S. 817 (1966).

$34 \mathrm{Id}$. at 181. For a discussion of these concerns as they relate to civil liability under the NASD's suitability rule, see text accompanying notes 43-52 infra.

3515 U.S.C. $\$ \S 780-3,78 \mathrm{q}, 78 \mathrm{cc}, 78 \mathrm{ff}$ (1970).

${ }^{36}$ See Mundheim, Professional Responsibilities of Broker-Dealers: The Suitability Doctrine, 1965 DUKE L.J. 445, 466 [hereinafter cited as Mundheim, The Suitability Doctrine].

37 See, e.g., Address by SEC Chairman William O. Douglas, Bond Club of Hartford, Connecticut, Jan. 7, 1938, quoted in The Report of tHe SPECTAL StUdx of SEcurities Markets of the Securities and Exchange Commussion, H.R. Doc. No. 95, 88th Cong., 1st Sess., pt. 4, at 694-95 (1963) [hereinafter cited as SPECrAL SrUdy]. The Special Study completed by the SEC in 1963 evidenced a new concern with formulating and promoting professional standards of conduct. See SPECCAL STUDY, pt. 1, at 159-62 (recommending that entry into the broker-dealer business be limited in order to insure adequate service); Mundheim, The Suitability Doctrine, supra note 36, at 445-46. Even full disclosure of relevant security information was considered to be inadequate for investor protection. The major result of the Special Study was the Securities Acts Amendments of 1964. 15 U.S.C. \$§ 77d, 78c, 78l-0, 780-3, 78p, 78t, 78w, 78ff (1970).
} 
All NASD rules play a significant role in the regulation of the securities industry, but only some NASD rules should be thought of as substituting for SEC regulation-namely, those designed to prevent fraud. Under the Colonial Realty test, these rules will assume legal significance, while those ethical NASD rules aimed at promoting just and equitable principles of trade will not.

This distinction between legal rules which do substitute for SEC regulation and ethical rules which do not is, of course, a vague one. In Colonial Realty, Judge Friendly offered a further test to distinguish those rules which would give rise to a private cause of action. "The case for implication [of a private right of action] would be strongest," he said, "when the rule imposes an explicit duty unknown to the common law."38 General standards of adequate service have traditionally been within the province of the common law and therefore would not give rise to a private right of action. On the other hand, rules which establish specific procedures designed to prevent fraud-section 27 of the Rules of Fair Practice, for example-create duties unknown to the common law and are therefore proper bases for civil liability. ${ }^{39}$

\section{Application of the Colonial Realty Test to The SUITability RULE}

\section{Section 2 of the NASD Rules of Fair Practice provides:}

In recommending to a customer the purchase, sale, or exchange of any security, a member shall have reasonable grounds for believing that the recommendation is suitable for such customer upon the basis of the facts, if any, disclosed by such customer as to his other security holdings and as to his financial situation and needs..$^{40}$

The Colonial Realty approach allows for the distinction of a standard of professional service or conduct from other rules of the NASD, like section 27 , which can be properly interpreted as establishing procedures designed to prevent fraud. Application of a simplified protection-of-the-public theory as promulgated in First Securities, would impose civil liability for violation of any of the NASD Rules of Fair Practice including the suitability rule. Unfortunate consequences could follow.

Although the 1964 Amendments increased SEC control over persons associated with a broker-dealer and gave the Commission the power to establish rules among nonmembers of the NASD, they did not alter the scheme whereby the NASD had primary responsibility for promoting high professional standards among its own members. 15 U.S.C. $\$ \$ 780(b)(8)-(10)(1970)$.

38358 F.2d at 182 .

39 Violations of a third category of rules-general rules prohibiting fraudulent activity-would not give rise to civil liability under Friendly's test, if they do not violate a duty unknown at common law. But violations of these rules would undoubtedly give rise to civil liability under the anti-fraud provisions of the securities laws.

40 CCH NASD MaNUaL art. III, \& 2, II 2152. 
One of the concerns of the SEC's Special Study of the Securities Markets $^{41}$ was the lack of initiative on the part of the NASD in certain problem areas. ${ }^{42}$ While it commended the NASD for formulating a general suitability rule it called for further definition of content and more effective enforcement. ${ }^{43}$ It is significant that the Commission recommended that the NASD take the responsibility for refining its rule and that the Commission has the power to review the disciplinary decisions and rule changes made by the NASD. ${ }^{44}$

The SEC relies on the NASD to define the NASD rule while reserving to itself the power to review interpretations of the rule. This emphasis on cooperation between industry and government is not without good reason. The securities industry has come to regard itself as a profession but is still essentially a selling business. ${ }^{45}$ The advising services offered by broker-dealers are not inseparable from their interest in sales. A major problem, then, is to attempt to coordinate the selling and advising activities in some manner which provides adequate service to customers. Few people outside the industry are in a position to judge the adequacy of the advice given, or even to set a standard on which to judge adequacy. ${ }^{46}$ Indeed the SEC's own version of the suitability rule does not define "reasonable grounds to believe" that a security is suitable, nor does it define "suitability" itself. ${ }^{47}$

The difficulty courts have in dealing with measures of adequate investment service may be illustrated by the development of the prudent-man rule. The rule relates to a trustee's responsibility for investing trust funds. As originally stated in Harvard College $v$. $A m o r y,{ }^{48}$ the legal obligation of the trustee was to exercise sound discretion, to emulate prudent men in the disposition of funds, with an eye to both income and risk. In the course of time, however, the relatively flexible rule became rigid. Courts made a distinction between speculation and investment. They concentrated on the riskiness of individual securities, in disregard of their potential for producing income and their place in an investor's securities holdings as a whole. At times trustees have been forbidden to purchase new securities, since there was no past history on which to judge riskiness. The rule now appears to be an obstacle to investments based on portfolio theory, in which relatively risky securities with high earning potential

41 Note 37 supra.

42 SPECIAT STUDY, supra note 37, pt. 4, at 669.

$43 I d$.

4415 U.S.C. $\S \S 780-3(\mathrm{~g})-(\mathrm{h}),(\mathrm{j})(1970)$.

45 See Mundheim, The Suitability Doctrine, supra note 36, at 446-47; Specrar STUdy, supra note 37 , pt. 1, at $240-42$.

46 Cf. Hoblin, A Stock Broker's Implied Liability to its Castomer for Violation of a Rule of a Registered Stock Exchange, 39 FORDEAMY L. REv. 253, 269-70 (1970).

4717 C.F.R. \& 240.15b10-3 (1972).

4826 Mass. (9 Pick.) 446 (1830). 
are balanced against practically risk-free securities, to produce the highest potential earnings at any given level of risk. ${ }^{49}$

In light of the role of precedent and the limitation of courts to case-by-case development, judicial enforcement of the suitability rule might result in a similarly rigid and unrealistic test. This is a significant danger in judicially enforcing standards of professional conduct in the securities area. A very closely related danger is the crippling of the scheme of cooperative regulation. The heavy hand of judicial enforcement might well destroy any initiative the NASD may have in attempting to define suitability. Any tentative guideline issued might be adopted by the courts as the basis for civil liability and become hardened into law. Fears of civil actions have apparently hindered the formation of more precise guidelines in the past..$^{50}$

Suitability is a vague concept offering little guidance to the people it affects. Hence a professionally unsound recommendation, with regard to what a court or jury considers a suitable security, is entirely possible. If liability were to attach in such a case, multiple claims may afflict the industry, for any investment which loses money often looks unreasonable to the customer. ${ }^{51}$ Civil liability for violation of specific procedures prescribed by the NASD to prevent fraud poses no such dangers. Here there is little discretion involved and any inadvertent violation could be considered negligent. It would not be unfair to hold a broker-dealer liable for its carelessness, particularly where it is possible to determine valid claims based on specific requirements.

\section{ConcLusion}

The approach the Seventh Circuit has taken in granting federal judicial remedies for violations of NASD rules is unfortunate. In using the simplified protection-of-the-public doctrine it has opened the door to claims based on any of the NASD Rules of Fair Practice. In contrast to this, the Second Circuit method for determining which NASD rules will serve as grounds for civil actions enables the courts to separate mere standards of professional conduct from rules designed to prevent fraud. The securities laws are designed to protect the public, but are designed in a certain way. Formulation of professional ethics for over-the-counter broker-dealers was committed to the NASD, the private regulator, subject to certain controls of the SEC, the government regulator. This system of private effort with limited public intervention appears necessary to create a system of ethics aimed at guaranteeing professional service in a selling business.

If a time comes when the federal courts decide that the statutory

49 Note, The Regulation of Risky Investments, 83 HaRv. I. Rev. 603, 614-16 (1970). For an excellent presentation of the portfolio theory, see Cohen, The Suitability Rule and Economic Theory, 80 YaLE L.J. 1604 (1971).

50 Mundheim, The Suitability Doctrine, supra note 36, at 463.

51 Cf. Belliveau, Discretion or Indiscretion, INsr. Irv., Aug. 1972, at 65, 66. 
scheme is inadequate to guarantee professional service and that civil liability must be implied to protect the investing public, the use of an analysis based on the Friendly criteria will point out that they are adopting mere standards of conduct. The responsibility for developing these standards in a flexible and realistic manner will fall directly on the courts. They should be aware that they will be doing more than creating a claim for relief for violation of professional duties; they will be creating the duties themselves.

While the result of the First Securities case appears correct, since the rule involved in that case was designed to prevent fraud, the Seventh Circuit's approach is unfortunate. The more careful method adopted by the Second Circuit in Colonial Realty is to be preferred. 